\title{
Retraction Note: Mechanisms of nanosized titanium dioxide-induced testicular oxidative stress and apoptosis in male mice
}

Xiaoyang Zhao ${ }^{1}$, Lei Sheng ${ }^{1}$, Ling Wang ${ }^{2}$, Jie Hong ${ }^{1}$, Xiaohong Yu ${ }^{1}$, Xuezi Sang ${ }^{1}$, Qingqing Sun ${ }^{1}$, Yuguan Ze and Fashui Hong ${ }^{1,3,4^{*}}$

\section{Retraction Note}

This article [1] has been retracted by the Editor. A committee at Soochow University has investigated this case and supports the decision to retract the article. Incorrect statistical methods were used to calculate mean and S.D. values and additional errors were made in determining 8-OHdG concentrations. It has come to light that Figure 1 and Figure 2 were published in a previous article [2]. The committee also found that some of the original data were missing. We apologize to the readership of Particle and Fibre Toxicology.

\footnotetext{
Author details

${ }^{1}$ Medical College of Soochow University, Suzhou 215123, China. 'Library of Soochow University, Suzhou 215123, China. ${ }^{3}$ Jiangsu Province Key Laboratory of Stem Cell Research, Soochow University, Suzhou 215007, China.

${ }^{4}$ Cultivation base of State Key Laboratory of Stem Cell and Biomaterials built together by Ministry of Science and Technology and Jiangsu Province,

Suzhou 215007, China.
}

Received: 23 June 2015 Accepted: 23 June 2015

Published online: 14 July 2015

\section{References}

1. Zhao X, Sheng L, Wang L, Hong J, Yu X, Sang X, et al. Mechanisms of nanosized titanium dioxide-induced testicular oxidative stress and apoptosis in male mice. Part Fibre Toxicol. 2014;11:47.

2. Gui S, Sang X, Zheng L, Ze Y, Zhao X, Sheng L, et al. Intragastric exposure to titanium dioxide nanoparticles induced nephrotoxicity in mice, assessed by physiological and gene expression modifications. Part Fibre Toxicol. 2013;10:4.

\footnotetext{
* Correspondence: hongfsh_cn@sina.com

${ }^{1}$ Medical College of Soochow University, Suzhou 215123, China

${ }^{3}$ Jiangsu Province Key Laboratory of Stem Cell Research, Soochow University,
} Suzhou 215007, China

\section{Submit your next manuscript to BioMed Central and take full advantage of:}

- Convenient online submission

- Thorough peer review

- No space constraints or color figure charges

- Immediate publication on acceptance

- Inclusion in PubMed, CAS, Scopus and Google Scholar

- Research which is freely available for redistribution

\section{Ciomed Central}

(c) 2015 Zhao et al. This is an Open Access article distributed under the terms of the Creative Commons Attribution License (http://creativecommons.org/licenses/by/4.0), which permits unrestricted use, distribution, and reproduction in any medium, provided the original work is properly credited. The Creative Commons Public Domain Dedication waiver (http:// creativecommons.org/publicdomain/zero/1.0/) applies to the data made available in this article, unless otherwise stated. 